\title{
In vitro effects of ellagic acid in C6 rat glioma cell cultures in terms of cytotoxicity and proliferation
}

\author{
Elajik asidin sıçan C6 glioma hücre kültürlerinde sitotoksisite ve proliferasyon üzerine in vitro \\ etkileri
}

\author{
Cenap Ekinci ${ }^{1}$, Aysun Ekinci ${ }^{1}$, Bülent Ahıshalı ${ }^{2}$, Ayhan Bilir ${ }^{2}$
}

\begin{abstract}
Objectives: Ellagic acid is a plant-derived polyphenolic compound. The aim of this study is to investigate in vitro effects of ellagic acid on the proliferation and viability of rat $\mathrm{C} 6$ glioma cell lineage depending on dose and time and also is to evaluate ultrastructural changes in C6 glioma spheroids.
\end{abstract}

Materials and methods: Effects of ellagic acid on rat $\mathrm{C} 6$ glioma cell line were investigated by using two-dimensional models of tumor cell culture depending on dose and time. The effects of Ellagic acid was evaluated as cell proliferation, cell viability, and synthesis phase of cell cycle, and cell structure at $24^{\text {th }}, 48^{\text {th }}, 72^{\text {nd }}$ hours. Cell structure was evaluated at $24^{\text {th }}$ and $72^{\text {nd }}$ hours in three dimensional cell culture spheroid models.

Results: Reducing effect of ellagic acid on cell proliferation and cell viability was seen in two dimensional cultures $(p<0.05)$. Increment or decrement were not seen in synthesis phase in two dimensional cultures $(p>0$. 05). Electron micrographs in which three dimensional cell culture spheroid models was investigated, structural changes was found to be different from the control group.

Conclusions: In the evaluation of effects of ellagic acid on rat $\mathrm{C} 6$ glioma cells using two-dimensional culture models, it was observed that ellagic acid caused reduced cell viability, deterioration in cell structure and prevented cell proliferation. J Clin Exp Invest 2012; 3 (3): 350-356

Key words: Ellagic acid, C6 glioma cells, cell culture, brain tumor, glioma

\section{ÖZET}

Amaç: Elajik asit bitkilerden elde edilen polifenolik bir bileşiktir. Bu çalışmanın amacı, elajik asidin sıçan C6 glioma hücre dizilerinde proliferasyon ve yaşama yeteneği üzerine in vitro etkilerini doz ve zamana bağlı olarak araştırmak ve C6 glioma küremsi cisimlerinde oluşan elektronmikroskopik değişiklikleri değerlendirmektir.

Gereç ve yöntem: Elajik asidin sıçan C6 glioma hücre dizisi üzerine etkileri doz ve zamana bağlı olarak iki boyutlu tümör hücre kültürü kullanılarak araştırıldı. Elajik asidin etkileri için üç boyutlu hücre kültürü küremsi modellerinde; hücre çoğalması, hücre yaşamsallığı, hücre döngüsünün sentez fazı ve hücre yapılarının 24,48 ve 72 . saatlerdeki durumu değerlendirildi.

Bulgular: İki boyutlu hücre kültürlerinde hücre yaşama yeteneği ve hücre çoğalması üzerinde elajik asidin baskılayıcı etkisi görüldü $(p<0.05)$. İki boyutlu hücre kültürlerinde hücre sentez fazında artma veya azalma gözlenmedi ( $p>0.05$ ). Üç boyutlu hücre kültürü küremsi modellerinde, elektronmikroskopik incelemede kontrol grubundan farklı yapısal değişiklikler bulundu.

Sonuç: İki boyutlu kültür modelleri kullanıldığında, elajik asidin sıçan C6 glioma hücre kültürleri üzerine olan etkilerinin değerlendirilmesi sonucunda; elajik asidin hücre yaşayabilirliğini azalttığı, hücre yapısında bozulmalara neden olduğu ve hücre çoğalmasını engellediği bulundu.

Anahtar kelimeler: Elajik asit, C6 glioma hücreleri, hücre kültürü, beyin tümörü, glioma

Abbreviations: DMSO; Dimethyl sulfoxide, DMEM/F12; Dulbecco's Modified Eagle Medium: Nutrient Mixture F-12, BrdU; Bromodeoxyuridine, PBS; Phosphate Buffer, BrDU-LI; Thymidine labeling index,

\footnotetext{
${ }^{1}$ Diyarbakır Kadın-Doğum ve Çocuk Hastalıkları Hastanesi, Diyarbakır, Türkiye

${ }^{2}$ Istanbul Üniversitesi, İstanbul Tıp Fakültesi, Histoloji-Embriyoloji AD, İstanbul, Türkiye
}

Correspondence: Cenap Ekinci,

Diyarbakır Kadın-Doğum ve Çocuk Hastalıkları Hastanesi, Diyarbakır, Türkiye Eposta: cenapekinci@yahoo.com.tr 


\section{INTRODUCTION}

Glioblastoma multiforme which is the most commonly seen primary brain tumor disseminates quickly. Treatment is surgical excision, postoperative radioterapy and chemoterapy. Unfortunately the mean survival is less than one year despite all treatment. There is no definitive treatment. New treatment options are being waited. Ellagic acid which is found in pomegranate, strawberries, raspberries, walnuts is phytochemical polyphenol compound. ${ }^{1-5}$ It is showed that, ellagic acid reduces growth of breast cancer, esophagus cancer, colon cancer, leukemia and neuroblastoma in cell culture studies. $^{6-8}$

Ellagic acid/chitosan composite biomaterial leads cancer cells to apoptosis in one layer cell culture in a study with using U87 glioblastoma and rat C6 glioma cell lineage. ${ }^{9}$ In this study we investigate in vitro effects of ellagic acid on the proliferation and viability of rat $\mathrm{C} 6$ glioma cell lineage.

\section{MATERIALS AND METHODS}

Rat C6 glioma cell line (ECACC no: 558807), which was taken from American Type Culture Collection was used in Laboratory of Istanbul University Histology and Embriology Department for this study.

a. Ellagic acid preparation for proliferation experiment: Ellagic acid which was taken $2 \mathrm{mg}$ has $302.192 \mathrm{~g} / \mathrm{mol}$ molecular weight and it was dissolved in $1324 \mu \mathrm{l}$ DMSO (Dimethyl sulfoxide) so $5 \mathrm{mM}$ ellagic acid stock solution was obtained by dilution of stock solution with DMSO. 50,10, $1 \mu \mathrm{M}$ application concentrations were reached by $100 \mu \mathrm{l}$ adding these doses to $5 \mathrm{ml}$ wells containing medium.

b. Experiment protocols in which ellagic acid doses were used: $100 \%$ live 500000 C6 glioma cells were inoculated in $5 \mathrm{ml}$ DMEM/F12 (Dulbecco's Modified Eagle Medium: Nutrient Mixture F-12) medium in each wells of six-well plate. Groups were determined as control group, $1 \mu \mathrm{M}, 10 \mu \mathrm{M}, 50$ $\mu \mathrm{M}$ and $100 \mu \mathrm{M}$ groups. Only $100 \mu \mathrm{LMSO}$ was given to control group. C6 glioma cells inoculation were performed in three wells for each Ellagic acid dose and control group. All groups were inoculated separately for 24,48 and 72 hours drug application and incubation was performed in a moist environment with $37^{\circ} \mathrm{C}$ and $5 \% \mathrm{CO}_{2}$ air-mixture.

At the end of 24,48 and 72 hours cells were collected separately from all experimental and control with $0.05 \%$ trypsin wells and these cells were centrifuged. After discard of supernatant part, sus- pension was made with $1 \mathrm{ml}$ medium and it was counted in counting chamber. Total cell counts were recorded to determine the proliferation rate. Cell suspension was mixed with $0.1 \%$ trypan blue dye with equal proportion. A drop of suspension was taken and stained dead cells and unstained live cells were counted under microscope so live cell ratio was determined (Table 1).

Table 1. Ellagic acid study groups

\begin{tabular}{llll}
\hline Doses & \multicolumn{3}{c}{ Ellagic acid time groups } \\
\cline { 2 - 4 } & 24 hour & 48 hour & 72 hour \\
\hline Control & 3 well & 3 well & 3 well \\
Ellagic Acid $1 \mu \mathrm{M}$ & 3 well & 3 well & 3 well \\
Ellagic Acid $10 \mu \mathrm{M}$ & 3 well & 3 well & 3 well \\
Ellagic Acid $50 \mu \mathrm{M}$ & 3 well & 3 well & 3 well \\
Ellagic Acid $100 \mu \mathrm{M}$ & 3 well & 3 well & 3 well \\
\hline
\end{tabular}

c. Immunohistochemical marking with Brdu in two-dimensional cell culture: Round lamellas were placed in 24 wells culture plates and 40000 cells were inoculated in each wells. Cell culture medium $1 \mathrm{ml}$ was placed in each well. Doses required for $1 \mu \mathrm{M}, 10 \mu \mathrm{M}, 50 \mu \mathrm{M}$ and $100 \mu \mathrm{M}$ ellagic acid groups are prepared from stock ellagic acid groups and $20 \mu \mathrm{l}$ applications were done. $20 \mu \mathrm{l}$ DMSO was applicated to control group. Three lamellae were prepared for each group. At the end of 24, 48 and 72 hours, cells were incubated with $20 \mu \mathrm{M} \mathrm{BrdU}$ (Bromodeoxyuridine) $(2 \mathrm{ml}$ medium $+100 \mu \mathrm{l} \mathrm{BrdU})$ for 1 hour at $37^{\circ} \mathrm{C}$. After upper medium was retreated and thrown, $1 \mathrm{ml}$ sterile PBS (Phosphate buffer) solution was applicated into the wells and stored in the incubator for 15 minutes. Cells were fixated in $70 \%$ ethanol in $-20^{\circ} \mathrm{C}$ for 30 minutes after retreat and thrown of PBS. Lamellae were dried at room temperature after ethanol was retreated. Dried lamellae for immunohistochemistry was rehydrated in PBS for 10 minutes then it was kept in $5 \% \mathrm{H}_{2} \mathrm{O}_{2}$ prepared in methanol for hydrogen peroxide inhibition in the dark. After application of ultra-V-block for 15 minutes in room temperature and humid environment to avoid non-specific antibody binding, it was kept in anti-BrdU antibody (NCL-BrdU; Zymed $1 / 50$ ) for an hour. After washing with PBS it was kept in secondary antibody for 30 minutes, after washing again it was kept in streptavidin peroxidase for 30 minutes. After washing with PBS it was kept in AEC chromogenic-substrate solution (AEC Substrate System; Zymed) for 20 minutes and then it was washed with distilled water. After floor stain- 
ing was made with Mayer's hematoxylin sections were closed with sealer. By counting marked and unmarked cells under a light microscope and $\mathrm{BrdU}$ index was determined.

d. Preparation of three dimensional cultures for electron microscopic evaluation: Inoculation was done for three dimensional cultures in agar coated cell culture dishes. 500000 cells in $5 \mathrm{ml}$ DMEM/F12 medium were inoculated into the each wells coated with solidified agar. Inoculation was done into the 6 wells for each control group, $1 \mu \mathrm{M}$ and $100 \mu \mathrm{M}$ ellagic acid groups. Mediums which were done in each 48 hours were waited for 7 days to form the spheroids from cells kept in incubator. While dose required for $100 \mu \mathrm{M}$ ellagic acid group was applicated directly from ellagic acid solution, dose required for $1 \mu \mathrm{M}$ ellagic acid group was prepared by dilution and $100 \mu \mathrm{l}$ applications were done. $100 \mu \mathrm{l}$ DMSO was applicated to control group. Spheroids were collected at $24^{\text {th }}$ and $72^{\text {nd }}$ hours and placed into different centrifuge tubes. After upper medium was retreated and thrown, 1 $\mathrm{ml} 0.1 \mathrm{M}$ phosphate buffered $2.5 \%$ gluteraldehyde solution was added and fixated under $4^{\circ} \mathrm{C}$ for 30 minutes. Post-fixation with $1 \%$ OsO4 for 60 minutes under $4^{\circ} \mathrm{C}$ was done after centrifuge and washing 2 times with phosphate buffer. After washing again with phosphate buffer for 10 minutes it was kept in $1 \%$ uranil acetate for 15 minutes. It was kept in $30 \%$ ethanol after phosphate buffer washing for 10 minutes. After that, it was kept in $50 \%$ ethanol for 10 minutes then $70 \%$ ethanol for 10 minutes then $90 \%$ ethanol twice for 10 minutes then pure propylenoxide for 10 minutes then $1 / 1$ ratio prepared propyleneoxide/epone mixture for 1 hour and finally it was kept in pure epone for 1 hour. After that it was embedded in tissue embedding capsules. It was kept in $37^{\circ} \mathrm{C}$ in the incubator for 18 hours. After trim of blocks which was taken from the incubator, target sections containing spheroids in $1 \mu \mathrm{m}$ semi-thin sections was detected. Then $70 \mathrm{~nm}$ thin sections on copper grids were done. It was evaluated under transmission electron microscopy after lead citrate and uranyl acetate contrasting.

e. Statistical analysis: Statistical analyses were performed under the SPSS for Windows software (version 12, SPSS Inc, Chicago, IL). Independent Student's T-test was used in all experimental results. Results are presented as mean \pm standard deviation and ranges. A two-tailed probability of $5 \%$ or less was considered statistically significant.

\section{RESULTS}

a. Results of ellagic acid kinetic cell proliferation experiments: Healthy cell proliferation pattern was seen in $\mathrm{C} 6$ tumor cells in the control group. Ellagic acid reduced cell count in $1 \mu \mathrm{M}$ concentration group at $48^{\text {th }}$ and $72^{\text {nd }}$ hours with related to control group and this was statistically significant. Reduction in 10 $\mu \mathrm{M}$ concentration only at $72^{\text {nd }}$ hour was statistically significant. $50 \mu \mathrm{M}$ concentration reduced cell count at $48^{\text {th }}$ hour and it was statistically significant. 100 $\mu \mathrm{M}$ concentration reduced cell count at $24^{\text {th }}$ and $48^{\text {th }}$ hour with related to control group but only reduction in $48^{\text {th }}$ hour was statistically significant $(p<0.05)$ (Graphic 1).

b. Cytotoxicity of ellagic acid: Application of ellagic acid in $1 \mu \mathrm{M}$ concentration reduced live cell ratio at $24^{\text {th }}$ and $48^{\text {th }}$ hour with related to control group and it was statistically significant $(p<0.01)$. On the other hand this concentration increased live cell ratio at $48^{\text {th }}$ hour significantly. Significant changes were not observed compared to control group in live cell ratio with $10 \mu \mathrm{M}$ application of ellagic acid. $100 \mu \mathrm{M}$ ellagic acid caused statistically significant reduction in the live cell ratio with compared to control group at $24^{\text {th }}$ hour $(p<0.01)$ (Graphic 2).

c. Effects of different concentration of ellagic acid on BrdU marking index (BrDU-LI): Application of $1 \mu \mathrm{M}$ concentration of ellagic acid cause increment at all times in BrDU-LI (Thymidine labeling index) values with compared to control group while this increment was statistically significant at $24^{\text {th }}$ hour $(p<0.05)$. BrDU-LI values were increased at $24^{\text {th }}$ and $72^{\text {nd }}$ hour with compared to control group by application of $10 \mu \mathrm{M}$ concentration of ellagic acid whereas increment in $24^{\text {th }}$ hour was statistically significant $(p<0.01)$. Application of $50 \mu \mathrm{M}$ concentration of ellagic acid cause increment at all times in BrDU-LI values with compared to control group whereas increment in $24^{\text {th }}$ and $48^{\text {th }}$ hour were statistically significant $(p<0.0001, p<0.0001)$. BrDU-LI values were significantly increased at all times with compared to control group by application of 100 $\mu \mathrm{M}$ concentration of ellagic acid $(p<0.05, p<0.001$, $p<0.001$ ) (Graphic 3; Picture 1, 2). 


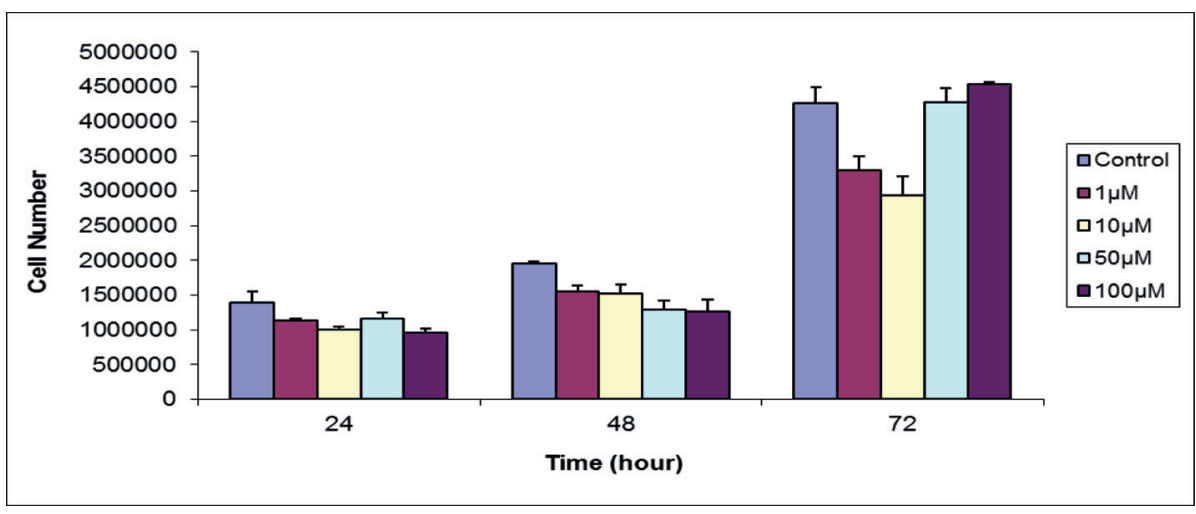

Graphic 1. Effects of ellagic acid on proliferation of rat C6 glioma cell depending on concentration and time ${ }^{*} \mathrm{p}<0.05$

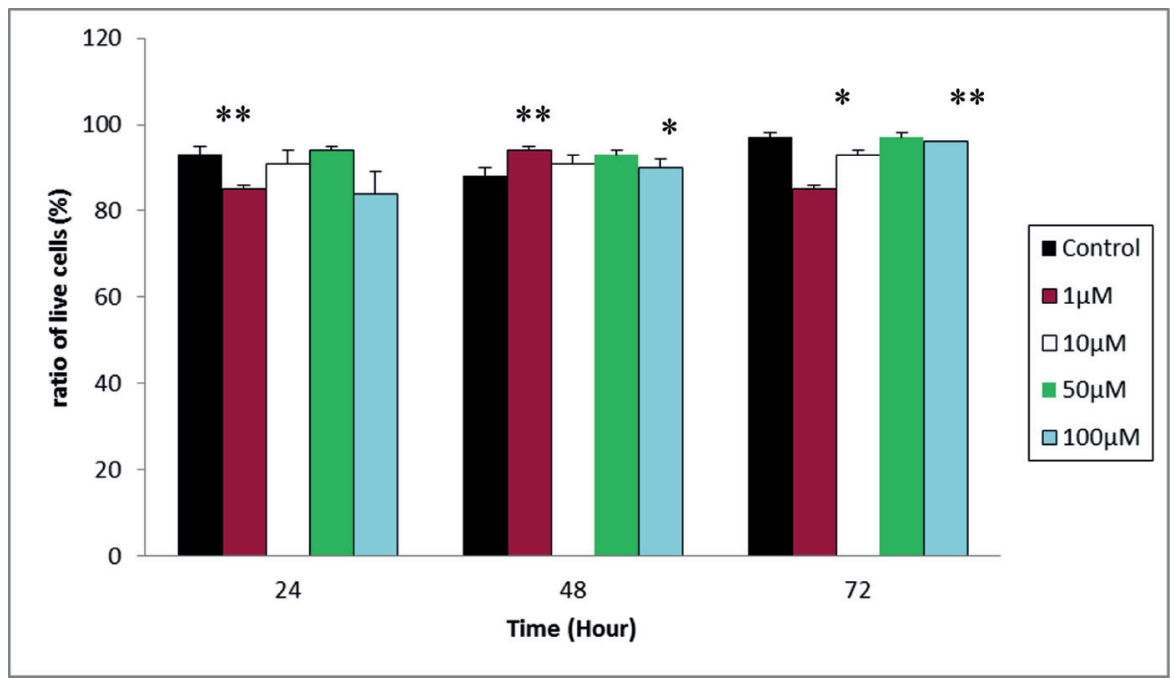

Graphic 2. The ratio of viability in the control group and application ellagic acid at 1, 10, 50 ve 100 micromolar $(\mu \mathrm{M})$ concentrations *: $p<0.05,{ }^{* *}: p<0.01$.

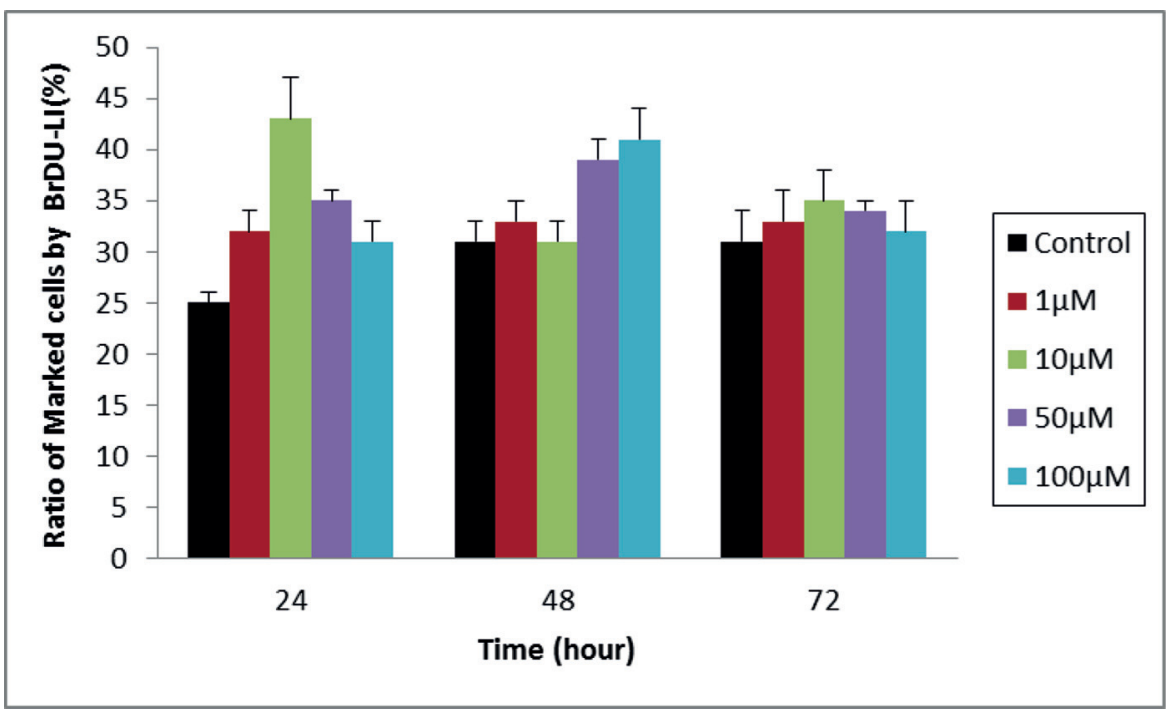

Graphic 3. Proliferation index in the control group and Ellagic acid applied cells at 1, 10, 50 ve 100 micromolar ( $\mu \mathrm{M})$ concentrations shown by bromodeoxyuridine labeling index 


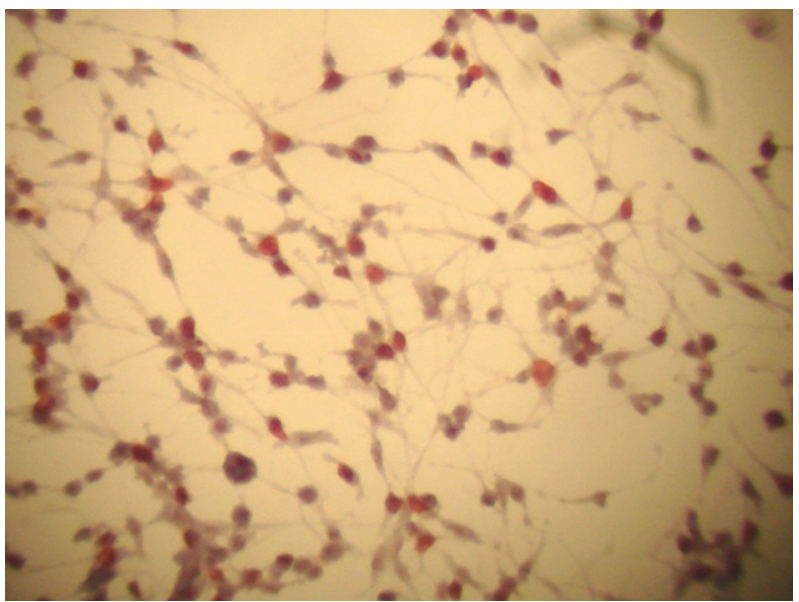

Picture 1. Control group two-dimensional cultures at $72^{\text {nd }}$ hour indicating numerous C6 glioma cells marked by BrdU X10

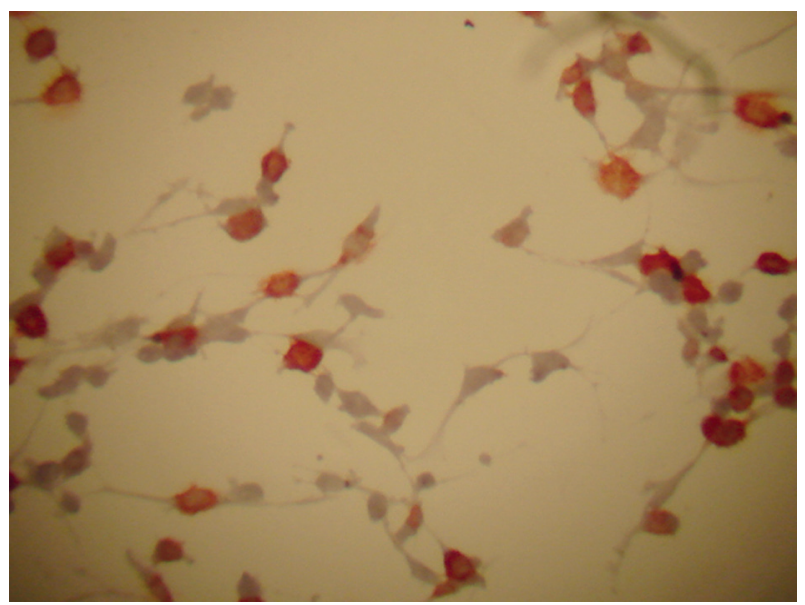

Picture 2. Ellagic acid $1 \mu \mathrm{M}$ dose applied group: C6 glioma cells marked by BrdU at $72^{\text {nd }}$ hour X20

\section{d. Electron microscopic evaluation of three} dimensional cell cultures: Tight regulations depending on 3 dimensional cellular contacts of $\mathrm{C} 6$ glioma cells generated an appearance similar to a typical tumor tissue to the spheroid in the control group at $24^{\text {th }}$ hour. Glioma cells which form spheroids have one nucleolus or two nucleoli and recessed and protruding euchromatic nucleus and their cytoplasms were seen electron-light in some cells and electron-dense in the other cells. Shelfshaped mitocondria with crista were seen less in some cells and more in the other cells. Plasma membranes of cytoplasm of adjacent cells were located closely in the outer surface of the spheroids and gaps which have 20 to $500 \mathrm{~nm}$ width contain electron dense material in some parts were found between two cell membranes. Plasma membrane gaps which did not contain electron dese material have 4-14 $\mathrm{nm}$ width. Microvilli like amorphous extensions formed by plasma membranes were in contact with each other in the intercellular space inside of the spheroid. As well as, inside spheroids in some cells electron dense material containing vacuoles surrounded by membrane and wide intercellular space were seen (Picture 3).

Necrotic area which was expected in a typical spheroid structure was not seen in this group spheroid. At the $24^{\text {th }}$ hour application of $1 \mu \mathrm{M}$ ellagic acid, inside electron dense cytoplasm of tumor cells forming spheroid, rich free ribosome and electron dense matrix, mitocondria with weak crista were drew attention. Connections between cells of outer surface of the spheroids were disappeared in some places and just below these cells wide intercellular spaces were occurred. In these wide intercellular spaces extending into the inner parts of the spheroids debris materials belonging to degenerated cells were found and in the cytoplasmic parts facing to these areas electron dense material containing vacuoles were seen.

At the $24^{\text {th }}$ hour ellagic acid application of 100 $\mu \mathrm{M}$ concentration, degenerated cell debris containing intercellular space widening were seen near the outer surface of the spheroids and this was similar to $24^{\text {th }}$ hour of $1 \mu \mathrm{M}$ ellagic acid application results.

At the $72^{\text {nd }}$ hour of $1 \mu \mathrm{M}$ application of ellagic acid, necrotic cells and apoptotic bodies were drew attention in the wide intercellular spaces inside the spheroids.

Near the outside face of the spheroids and inside of the spheroids intercellular space widening areas were found at $72^{\text {nd }}$ hour of application of 100 $\mu \mathrm{M}$ ellagic acid. In these areas microvillus like amorphous extensions were abundant and degenerated cell debris was not found (Picture $3,4,5$ ).

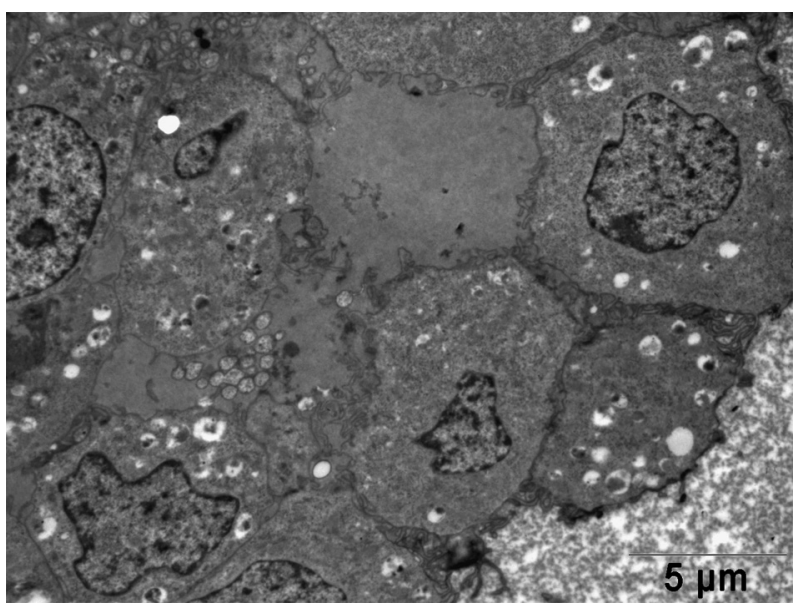

Picture 3. Unchained ribosomes and mitochondrias with obscure cristas. Spheroid structure of C6 glioma cells in 
three dimensional cultures at $24^{\text {th }}$ hour under $1 \mu \mathrm{M}$ dose of Ellagic acid.

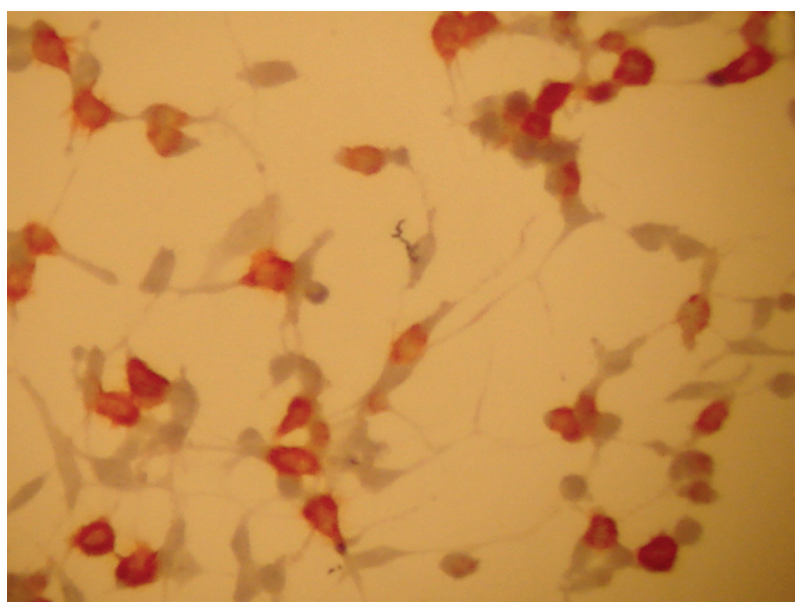

Picture 4. Ellagic acid $100 \mu \mathrm{M}$ dose applied group; C6 glioma cells marked by BrdU at $72^{\text {nd }}$ hour X20

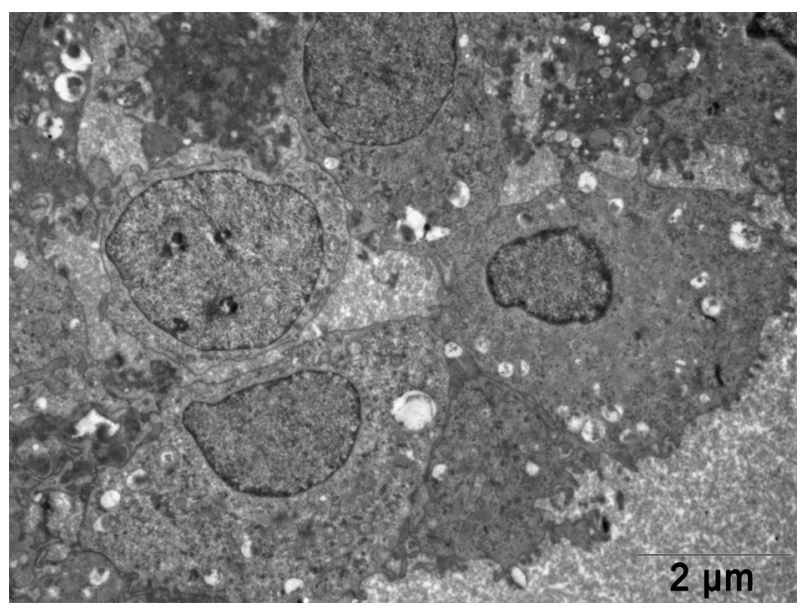

Picture 5. Sferoid structure of C6 glioma cells in three dimensional cultures at $24^{\text {th }}$ hour under $100 \mathrm{~m} \mu \mathrm{M}$ dose of Ellagic acid. Cell debris was observed in expanding area under the spheroid surface.

Statistical evaluation results: As a result in two dimensional cell culture model ellagic acid led to reduction in cell proliferation with compared to control group. In S-phase evaluation ellagic acid led to increment in all concentration. Live cell ratio was increased at $48^{\text {th }}$ hour, decreased in other intervals.

\section{DISCUSSION}

In our study, we found that ellagic acid reduced cell proliferation and viability ratio in C6 glioma cells which was dose and time dependent. Statistically significant cell proliferation reduction was seen in $1,50,100 \mu \mathrm{M}$ doses of ellagic acid at $48^{\text {th }}$ hour and $1,10 \mu \mathrm{M}$ doses at $72^{\text {nd }}$ hour. As well as statistically significant reduction in cell proliferation was seen in $1 \mu \mathrm{M}$ dose at $72^{\text {th }}$ hour, $50 \mu \mathrm{M}$ dose at $48^{\text {th }}$ hour, $100 \mu \mathrm{M}$ dose at $24^{\text {th }}$ hour.

Studies to clarify the mechanism of antitumoral effects of ellagic acid reported that drug did not cause any change in expression level of tumor suppressor gene P53 but it increase expression of cyclin-dependent kinase inhibitor p21 (waf1/Cip1). ${ }^{10}$

On the other hand ellagic acid increases cytochrome c level released from mitochondria to the cytosol and it increases caspase- 3 and caspase- 9 which are important proteases. It is reported that in this way ellagic acid induced apoptosis. ${ }^{11}$

In a study on SH-SY5Y human neuroblastoma cells, ellagic acid decreased cells in $S$ phase compared to control group and this was statistically significant, whereas cells in G2/M phase were slightly increased and cells in G0/G1 phase were significantly increased. ${ }^{12,13}$ Mertens et al. reported that $10 \mu \mathrm{M}$ ellagic acid application did not effect in MOLT-4 human leukemia cell cycle compared to control group at $12^{\text {th }}, 24^{\text {th }}$ and $48^{\text {th }}$ hour. ${ }^{14}$ In a study on CaSki cervical cancer cells $10 \mu \mathrm{M}$ ellagic acid stops cell cycle in $\mathrm{G} 1$ phase. ${ }^{10}$

Li et al. reported that, 5, 10, 25 and $50 \mu \mathrm{M}$ doses of ellagic acid increased the cell ratio in G0/G1 phase of cell cycle and decreased cell ratio in G2/M phase of cell cycle in T24 human bladder cancer cells. ${ }^{15}$

In our study, effect of different concentration of ellagic acid on S phase of C6 glioma cell cycle which was expressed as BrdU-LI was increased with compared to control group in all concentrations and in time period and no decrement was seen in all concentrations and in time period. This result was in line with a study about effects of ellagic acid on Caco-2 human colon cancer cell descendants by Larossa et al. In this study 1, 10 and $30 \mu \mathrm{M}$ doses of ellagic acid were applicated at $24^{\text {th }}, 48^{\text {th }}$ and $72^{\text {nd }}$ hour and cyclin levels were investigated. It was reported that ellagic acid reduced cyclin A and B1 and it increased cyclin $E$ levels with related to time and dose so cell was arrested at $S$ phase of the cell cycle..$^{11}$ This study supports our finding that is while ellagic acid reduced cell proliferation and viability and it increased the cell ratio in $S$ phase expressed as BrdU-LI value.

Different mutations in a particular cell's descendants may cause the diversity of polyphenol treatment outcomes and the cell cycle halt in different phases. In our study, effects of ellagic acid on cell viability and proliferation showed different statistical significance lines during administered dose and time interval. Effects of ellagic acid on the cell cycle may have temporary features and pathways to es- 
cape from cell destruction may arise in tumor cell population. . $11,12,14-17^{-17}$

To our knowledge this study which evaluates effects of ellagic acid in three dimensional spheroid model by using electron microscopy is the first study. Taking into account the three-dimensional arrangement of solid tumors multicellular tumor spheroids which were developed to form more suitable in vitro systems reflect three dimensional growth and organizations of tumors quite realistically, as a result intercellular relations in tumor and microenvironmental conditions can be presented clearly. ${ }^{18}$ Integrins have major role in cell-cell contact in spheroids. Integrins which bind to spheroid cell skeleton also bind intercellular matrix. In this way, cell-cell connection and spheroid integrity can be provided. It is known that integrin release is organized by spheroid microenvironment. ${ }^{19}$ In our study, connections between cells located in the outer surface of the C6 glioma spheroids were disappeared in some places and just below these cells wide intercellular spaces were occurred.

In these wide intercellular spaces extending into the inner parts of the spheroids debris materials belonging to degenerated cells were seen. In our study, this condition with reduction in cell proliferation and cell viability caused by ellagic acid effect integrin release organized by spheroid microenvironment and reduce connections of the cells in each other and external matrix.

In the way of these findings, microscopic and molecular studies are needed to find mechanism of effects of ellagic acid on different cell types and further studies are needed to find synergistic effects of this drug in combination with different chemotherapeutic agents.

In conclusion, ellagic acid which reduced cell proliferation and cell viability increased BrdU-LI showing $S$ phase of the cell cycle in $\mathrm{C} 6$ glioma cells.

\section{REFERENCES}

1. Karakaya S. Bioavailability of phenolic compouns. Crit Rev Food Sci Nutr 2004;44(4):453-64.

2. Yang CS, Landau JM, Huang MT, Newmark HL. Inhibition of carcinogenesis by dietary polyphenolic compounds, Ann Rev Nutr 2001:21(3):381-406.

3. Navinda P, Seeram, Lynn S, et al. In vitro antiproliferative apoptotic and antioxidant activities of punicalagin, ellagic acid and total pomegranate tannin extract are enhanced in combination with other polyphenols as found in pomegranate juice. J Nutr Biochem 2005:6(2);360-3.

4. Quinones-Hinojasa A, Sanai N, Smith JS, McDermott MW. Techniques to assess proliferative potential of brain tumors. J Neurooncol 2005:74(1);19-30.
5. Vekiari A, Gordon M.H, Garcia-Macias P, Labrinea $\mathrm{H}$. Extraction and determination of ellagic acid contentin chesnut bark and fruit. Food Chemistry 2008:110(4);1007-11.

6. Falsaperla M, Morgia G, Tartarone A, Ardito R, Romano G. Support ellagic acid therapy in patients with hormone refractory prostate cancer (HRPC) on standard chemotherapy using vinorelbine and estramustine phosphate. Eur Urol 2005:47(3);449-55.

7. Strati A, Papoutsi Z, Lianidou E, Moutsatsou P. Effect of ellagic acid on the expression of human telomerase reverse transcriptase (h TERT) $\alpha+\beta+$ transcript in estrogen receptor-positive MCF-7 breast cancer cells. Clin Biochem 2009:42(13);1358-62.

8. Alexander C, Whitley G, Stoner D, Darby M, Vale T. Intestinal epithelial cell accumulation of the cancer preventive polyphenol ellagic cid-extensive binding to proteinamd DNA. Biochem Pharmocol 2003:66(8);907-15.

9. Sungwoo Kim, Mostafa W. Gaber, et al. The inhibition of glioma growth in vitro and in vivo by chitoan/ ellagic acid composite biomaterial, Biomaterials 2009:30(27);4743-51.

10. Narayanan BA, Geoffroy O, Willingham MC, Re GG, Nixon DW. p53/p21(WAF1/CIP1) exspression and its possible role in $\mathrm{G} 1$ arrest and apoptosis in ellagic acid treated cancer cell, Cancer Lett 1999:136(2);215-21.

11. Larrosa M, Tomas-Barberan FA, Espin JC. The dietary hydrlysable tannin punicalagin releases ellagic acid that induces apoptosis in human colon adenocarcinoma Caco-2 cells by using the mitochondrial pathway. J Nutr Biochem 2006:17(5);611-25.

12. Fjaeraa C, Nanberg E. Effect of ellagic acid on proliferasyon, cell adhesion an apoptosis İn $\mathrm{SH}$ SY5Y nuroblastoma cells, Biomed \& Pharmacother 2009:63(2);254-61.

13. Vermeulen K, Berneman ZN, vanBockstaele DR. Cell cycle and apoptosis. Cell Prolif 2003:36(1);165-75.

14. Susanne U. Mertents-Talcott, Susan S. Percival. Ellagic acid and quercetin interact synergistically with reveratrol in the induction of apoptosis and cause transient cel cycle arrest in human leukemia cells. Cancer Lett 2005:218(2);141-51.

15. Li TM, Chen GW, Su CC, et al. Ellagic acid induced p53/p21expresion, G1 arrest and apoptozis in human bladder cancer T24 cells. Anticancer Res 2005:25(8);971-9.

16. Tasaki M, Umemura T, Maeda M, et al. Safety assesment of ellagic acid, a food additive, in a subchronic toxicity study using F344 rats. Food Chem Toxicol 2008:46(9);1119-24.

17. Sharma G, Italia JL, Sonaje K, Tikoo K, Ravi Kumar MNV. Biodegradale in situ gelling system for subcutaneous administration of ellagic acid and ellagic acid loaded nanoparticles: evaloation of their antioxidant potantial against cycosporine induced nephrotoxicity in rats. J Control Release 2007:118(1);27-37.

18. Carlsson J, Yuhas JM. Liquid-overlay culture o cellular spheroids: Resent results. Cancer Res 1984:95(1);1-23.

19. Santini MT, Gabriella R. Three dimensional spheroid models in tumor biology. Pathobiology 1999;67(1);148-57. 